УДК 330.111.4:332.14

DOI: https://doi.org/10.37320/2415-3583/12.26

Шашина М.В.

кандидат економічних наук, доцент кафедри економіки і підприємництва, Національний технічний університет України «Київський політехнічний інститут імені Ігоря Сікорського» ORCID: https://orcid.org/0000-0001-6676-3316

\title{
РІВЕНЬ ІННОВАЦІЙНОГО ПОТЕНЦІАЛУ ЦЕНТРАЛЬНОГО РЕГІОНУ УКРАЇНИ
}

У статті на основі інтегрального індексу інновачійного потенціалу визначено оцінку рівня інновачійної сфери Центрального регіону Украӥни. Визначено поняття інноваційного потенціалу та чинники його розвитку. Досліджено процеси у сфері інновачійної діяльності регіону. Висвітлено позитивні та негативні тенденції в сфері впровадження інновацій. Встановлено відсутність упровадження кластерного підходу до реалізації інноваџійного потенціалу. Передумовами розширення інноваційного потенціалу визначено локальні та національні стимули: фінансове сприяння промисловим підприємствам шляхом пільгового оподаткування, компенсації відсоткової ставки підприємствам, які впроваджують інновачійні прочеси, компенсації підприємствам, які орієнтовані на експорт високотехнологічної продукиії, місиеві стимули.

Ключові слова: інновачійний потенціал, рівень розвитку інновацій, високотехнологічний сектор, кластерний nidxid.

Постановка проблеми. В Україні актуалізується розвиток інноваційного потенціалу на основі кластерного підходу, що визначено на державному рівні у Стратегії розвитку сфери інноваційної діяльності [14]. Розвиток креативної економіки зумовлює зміну підходів до поняття “інноваційний потенціал економіки”. Витрати на дослідження та розробки, чисельність нау- ковців є вихідними факторами забезпечення інноваційного розвитку країн, проте вагомими доповнюючими факторами формування інноваційного потенціалу слугують стан співпраці приватного, державного секторів та університетів, фінансування технічної підтримки, розвиток навичок зайнятих в інноваційній сфері. Натомість країни, що вийшли зі складу Радянського 
Союзу, зокрема Україна, характеризуються сировинною структурою економіки, відсутністю ефективної економічної політики протягом тривалого часу. Розвинені країни забезпечили розвиток інноваційного потенціалу завдяки реалізації кластерного підходу. Це означає, що дослідження інновацій доцільно здійснювати 3 урахуванням територіальних особливостей. Зазначене потребує дослідження інноваційного потенціалу регіонів України та виявлення ключових рушіїв розвитку інноваційного потенціалу.

Аналіз останніх досліджень і публікацій. Інновації визнані рушійною силою в національному економічному зростанні не тільки в розвинених країнах, а й у країнах, що розвиваються. Інноваційний потенціал можна виміряти на основі показників розвитку людського капіталу, рівня наукових досліджень, патентів, продукції високотехнологічних галузей (авіаційної, машинобудування, хімічної). Науковцями доведено вплив зростання цих показників на економічний розвиток країни. Найбільш ефективним методом оцінювання інноваційного потенціалу виступає емпіричне дослідження еволюції інноваційної системи, що дає змогу оцінити інноваційний розвиток країни, регіону, території [5]. У науковій літературі останніх років запропоновано різні методики оцінки інноваційного потенціалу на основі показників [2]. Оцінка регіонального інноваційного потенціалу забезпечує більш ефективний аналіз [9] інновацій. Оцінка рівня інноваційності регіону забезпечує розроблення пропозицій щодо вдосконалення методики економічної безпеки відповідно до рівня інновацій країни та методів управління інноваціями [7]. Заходи управління інноваціями засновані на реалізації інноваційної політики, яка впливає на інноваційну діяльність [4]. Методологічні підходи оцінки інноваційного потенціалу використовуються для оцінки інноваційної безпеки, для моніторингу стану національної безпеки країни [8]. Інноваційний потенціал розглядається як сукупність різних видів ресурсів (матеріальних, фінансових, наукових, науково-технічних, інтелектуальних, інформаційних та інших), які дають сукупність можливостей для реалізації заходів зі здійснення інноваційної діяльності. Чинниками розвитку інноваційного потенціалу є доступ компаній до фінансування, людський капітал та зовнішня торгівля. Інноваційний потенціал зростає за умов фінансування, більшого обсягу людського капіталу та залучення регіону до зовнішньої торгівлі [1]. Інноваційний потенціал розвивається завдяки високому рівню конкуренції, а міжнародні зв'язки компаній сприяють розвитку практики відкритих інновацій [3]. Основні проблеми інноваційного розвитку регіонів України пов'язані з інституційним, соціальним та політичним розвитком та трансформаційним переходом $[10 ; 14]$. Структурні особливості економіки регіонів України визначають їхній інноваційний потенціал: велика частка зайнятості в аграрному секторі; низька частка сфери послуг у ВВП; велика частка так званих проблемних секторів економіки; слабкий фінансовий сектор; низький рівень розвитку технічної інфраструктури [6].

Мета статті полягає у дослідженні інноваційного потенціалу Центрального регіону України на основі системи показників сфери інноваційної діяльності.
Виклад основного матеріалу дослідження. Відповідно до методики районування, розробленої вченими Національної академії наук України М.I. Долішнім, М.М. Паламарчук, О.М. Паламарчук, розрізняють шість макрорегіонів: 1) Центральний (Вінницька, Житомирська, Київська, Хмельницька, Черкаська, Чернігівська області та м. Київ); 2) Донецький (Східний) (Доненька і Луганська області); 3) Західний (Волинська, Закарпатська, Івано-Франківська, Львівська, Рівненська, Тернопільська, Чернівецька області); 4) Придніпровський (Центрально-Східний) (Дніпропетровська, Запорізька, Кіровоградська області); 5) Причорноморський (Південний) (Миколаївська, Одеська, Херсонська області, АР Крим та м. Севастополь); 6) Харківський (Північно-Східний) (Полтавська, Сумська, Харківська області) [13]. Узагальнення наявних методичних підходів щодо районування наведено в праці Л. Чмирьова та Н. Федяй [15]. На основі запропонованого М. Глізнуца [11, 12, с. 111-115] групування складників для проведення аналізу інноваційного потенціалу складено таблиці вихідних даних для визначення інтегральних індексів інноваційного розвитку.

Загалом інноваційний потенціал Центрального регіону характеризується стабільністю впровадження інновацій промисловими підприємствами. Поступово впроваджуються нові або вдосконалені методи обробки або виробництва продукції (табл. 1), відповідно стабільністю характеризується освоєння виробництва інноваційної продукції, нових технологій.

Запровадження нових технологій та інноваційних процесів прямо впливає на обсяги реалізації інноваційної продукції (табл. 2). Кількість підприємств, які реалізували інноваційну продукцію, скоротилася у 2017 році, що можна пояснити циклічністю інновацій. Суттєво зріс показник кількості підприємств, що реалізували продукцію, що була новою для ринку, та кількість тих економічних агентів, які випускали абсолютно нову продукцію в межах підприємства.

На рівень інноваційного потенціалу впливає матеріально-технічна база підприємств (табл. 3). Практично не змінилася кількість організацій, які виконують наукові та науково-технічні роботи, за регіонами. Відповідно, кількість виконаних наукових та науково-технічних робіт за регіонами змінювалася лише під впливом макроекономічних чинників.

Попередні проаналізовані чинники визначають спроможність регіонів України до високотехнологічного експорту: кількість підприємств, що реалізували інноваційну продукцію за межі України, дещо зросла. Обсяг реалізованої інноваційної продукції за межі України у 2017 році зріс на 27\%, у 2018 році - на 11\%.

Відсоток реалізованої інноваційної продукції за межі України до загального рівня реалізованої інноваційної продукції зріс у 2017-2018 роках порівняно з 2016 роком.

Для оцінки інноваційного потенціалу запропоновано метод оцінки на основі інтегрального показника. Для його визначення використано нормовані значення індикаторів інноваційного потенціалу на основі відхилень $\left(x_{i j}-a\right)$ та стандартизація показників розмахом варіації на основі мінімальних та максимальних значень індикаторів. 
Таблиця 1 - Вихідні дані для розрахунку індексу впровадження інновацій

\begin{tabular}{|c|c|c|c|c|c|c|c|c|c|c|c|c|}
\hline & \multicolumn{3}{|c|}{$\begin{array}{c}\text { Кількість промислових } \\
\text { підприсмств, що } \\
\text { впроваджували } \\
\text { інноваційні процеси, } \\
\text { од. }\end{array}$} & \multicolumn{3}{|c|}{$\begin{array}{c}\text { Кількість промислових } \\
\text { підприємств, що } \\
\text { впроваджували нові або } \\
\text { вдосконалені методи } \\
\text { обробки або виробництва } \\
\text { продукції, од. }\end{array}$} & \multicolumn{3}{|c|}{$\begin{array}{c}\text { Кількість промислових } \\
\text { підприємств, } \\
\text { що освоювали } \\
\text { виробництво } \\
\text { інноваційних видів } \\
\text { продукції, од. }\end{array}$} & \multicolumn{3}{|c|}{$\begin{array}{c}\text { Кількість промислових } \\
\text { підприємств, } \\
\text { що освоювали нові } \\
\text { технологї̈, од. }\end{array}$} \\
\hline & 2016 & 2017 & 2018 & 2016 & 2017 & 2018 & 2016 & 2017 & 2018 & 2016 & 2017 & 2018 \\
\hline Вінницька & 23 & 27 & 39 & 25 & 30 & 35 & 24 & 32 & 38 & 18 & 20 & 22 \\
\hline Житомирська & 22 & 25 & 31 & 20 & 24 & 38 & 18 & 20 & 23 & 20 & 22 & 23 \\
\hline Київська & 35 & 37 & 42 & 15 & 18 & 21 & 13 & 16 & 18 & 3 & 4 & 7 \\
\hline Хмельницька & 17 & 8 & 8 & 5 & 2 & 3 & 8 & 3 & 7 & 14 & 6 & 5 \\
\hline Черкаська & 7 & 8 & 18 & 7 & 10 & 14 & 9 & 12 & 16 & 10 & 10 & 11 \\
\hline Чернігівська & 7 & 9 & 12 & 0 & 0 & 2 & 4 & 7 & 8 & 5 & 6 & 9 \\
\hline Україна & 723 & 679 & 739 & 400 & 456 & 451 & 410 & 450 & 467 & 332 & 367 & 400 \\
\hline
\end{tabular}

Таблиця 2 - Вихідні дані для розрахунку індексу реалізації інноваційної продукції, нової для ринку і/або для підприємства

\begin{tabular}{|c|c|c|c|c|c|c|c|c|c|}
\hline \multirow[t]{2}{*}{$\begin{array}{c}\text { Області } \\
\text { центрального } \\
\text { регіону }\end{array}$} & \multicolumn{3}{|c|}{$\begin{array}{c}\text { Кількість підприсмств, що } \\
\text { реалізували інноваційну } \\
\text { продукцію, од. }\end{array}$} & \multicolumn{3}{|c|}{$\begin{array}{l}\text { Кількість підприсмств, що } \\
\text { реалізували продукцію, що } \\
\text { була новою для ринку, од. }\end{array}$} & \multicolumn{3}{|c|}{$\begin{array}{c}\text { Кількість підприємств, } \\
\text { що реалізували продукцію, } \\
\text { що була новою тільки для } \\
\text { підприємства, од. }\end{array}$} \\
\hline & 2016 & 2017 & 2018 & 2016 & 2017 & 2018 & 2016 & 2017 & 2018 \\
\hline Вінницька & 20 & 21 & 28 & 6 & 7 & 10 & 17 & 20 & 25 \\
\hline Житомирська & 20 & 22 & 28 & 5 & 5 & 7 & 18 & 20 & 24 \\
\hline Київська & 20 & 22 & 27 & 4 & 5 & 7 & 15 & 19 & 23 \\
\hline Хмельницька & 12 & 4 & 10 & 2 & - & - & 11 & 4 & 10 \\
\hline Черкаська & 9 & 12 & 21 & 2 & 3 & 3 & 14 & 17 & 23 \\
\hline Чернігівська & 6 & 7 & 9 & 2 & 2 & 3 & 4 & 5 & 7 \\
\hline Україна & 632 & 450 & 674 & 114 & 124 & 192 & 503 & 377 & 557 \\
\hline
\end{tabular}

Таблиця 3 - Вихідні дані для розрахунку індексу матеріально-технічної бази

\begin{tabular}{|c|c|c|c|c|c|c|c|c|c|}
\hline \multirow[t]{2}{*}{$\begin{array}{c}\text { Області } \\
\text { центрального } \\
\text { регіону }\end{array}$} & \multicolumn{3}{|c|}{$\begin{array}{c}\text { Кількість організацій, } \\
\text { які виконують наукові та } \\
\text { науково-технічні роботи за } \\
\text { регіонами, од } \\
\end{array}$} & \multicolumn{3}{|c|}{$\begin{array}{c}\text { Кількість виконаних наукових } \\
\text { та науково-технічних робіт } \\
\text { за регіонами, тис. грн }\end{array}$} & \multicolumn{3}{|c|}{$\begin{array}{c}\text { Обсяг наукових та науково- } \\
\text { технічних робіт, виконаних } \\
\text { власними силами наукових } \\
\text { організацій за регіонами, тис. грн }\end{array}$} \\
\hline & 2016 & 2017 & 2018 & 2016 & 2017 & 2018 & 2016 & 2017 & 2018 \\
\hline Вінницька & 19 & 20 & 21 & 118564,1 & 125489,7 & 139946 & 2998,78 & 3786,2 & 3999,3 \\
\hline Житомирська & 22 & 24 & 25 & 97257,3 & 116926,1 & 124296 & 2118,4 & 1527,8 & 1296,7 \\
\hline Київська & 26 & 30 & 33 & 1498253 & 1489234 & 1639201 & 3091,5 & 3017,2 & 3109,2 \\
\hline Хмельницька & 8 & 8 & 8 & 12525,9 & 16974,4 & 20502,7 & 566,5 & 520,5 & 924,6 \\
\hline Черкаська & 13 & 14 & 14 & 212360 & 251320 & 251683 & 1998 & 2589 & 2345 \\
\hline Чернігівська & 13 & 14 & 16 & 1000652 & 1045872 & 1104672 & 2345 & 2491,4 & 2754,9 \\
\hline Україна & 972 & 963 & 985 & 10954703 & 12597483 & 16009286 & 1146032,5 & 1340844,1 & 1610011,8 \\
\hline
\end{tabular}

Для визначення інтегрального показника застосуємо нормовані значення індикаторів інноваційного потенціалу на основі відхилень $\left(x_{i j}-a\right)$ та стандартизовані варіаційним розмахом $\left(x_{\max }-x_{\min }\right)$.

Для показників інноваційного потенціалу, які характеризують його розвиток, тобто зростання показника, що вказує на позитивні тенденції, доцільно використати таку формулу розрахунку:

$$
Y_{i j}=\left(X_{i j}-\min X_{i j}\right) /\left(\max X_{i j}-\min X_{i j}\right),
$$

де $Y_{i j}$ - нормований і-й показник в ј-й сукупності, $X_{i j}$ - значення і-го показника в ј-й сукупності, $\min X_{i}$ - мінімальне значення і-го показника, $\max X_{i}$ - максимальне значення і-го показника.
Таким чином, чим більше значення фактичного показника інноваційного потенціалу, тим більше нормований показник буде наближатися до 1.

Для показників інноваційного потенціалу, наближення значення яких до мінімального характеризує розвиток (наприклад, знос основних засобів), доцільно використати таку формулу розрахунку:

$$
Y_{i j}=\left(\max X_{i j}-X_{i j}\right) /\left(\max X_{i j}-\min X_{i j}\right) .
$$

Величина $Y_{i j}$ буде наближуватися до 1 за наближення фактичного значення $X_{i j}$ до $\min X_{i j}$.

Інтегральний показник для кожного складника інноваційного потенціалу визначається як середнє значення відібраних коефіцієнтів за визначений календар- 
ний період, що зумовлено рівнозначністю між собою усіх показників кожної групи.

При цьому під інтегральним показником розуміється показник, що обчислюється в результаті зважування визначеної комбінації індикаторів та комплексно характеризує інноваційний потенціал і стан управління потенціалом. Інтегральний показник включатиме усі визначені складники, виявлені у процесі аналізу інноваційного потенціалу на основі індикаторів:

$$
I_{s d}=\frac{\left(I_{i j}^{1}+I_{i j}^{2}\right)}{n}=\frac{\sum_{i=1}^{n} I_{j=1}^{k}}{n},
$$

де $I_{s d}$ - інтегральний показник, що характеризує економічний потенціал територій, $I_{i j}$ - це нормований i-й показник в ј-й сукупності.

Найбільш проблемним індикаторам інноваційного розвитку слід присвоювати найбільшу вагу, що в подальшому дає змогу визначити території та регіони, які характеризуються найменшим рівнем економічного розвитку. Вище значення індексу характеризуватиме вищий рівень розвитку інноваційного потенціалу території.

Розрахований інтегральний показник розвитку інноваційного потенціалу Центрального регіону України у 2016-2018 роках за даними табл. 1-4, свідчить про низький рівень інновацій.

Суттєво показник зріс у 2017 році завдяки позитивним змінам у кількості підприємств, що реалізували продукцію, яка була новою для ринку, та тих, що реалізували інноваційну продукцію за межі України. Впровадження інноваційних процесів на підприємствах було стимулюючим фактором інноваційного розвитку у 2018 році. Загалом технологічність галузей економіки Центрального регіону України залишається

Таблиця 4 - Вихідні дані для розрахунку індексу реалізації інноваційної продукції за межі України

\begin{tabular}{|c|c|c|c|c|c|c|c|c|c|}
\hline \multirow[t]{2}{*}{$\begin{array}{c}\text { Області } \\
\text { центрального } \\
\text { регіону }\end{array}$} & \multicolumn{3}{|c|}{$\begin{array}{c}\text { Кількість підприсмств, що } \\
\text { реалізували інноваційну } \\
\text { продукцію за межі України, } \\
\text { од. }\end{array}$} & \multicolumn{3}{|c|}{$\begin{array}{c}\text { Обсяг реалізованої інноваційної } \\
\text { продукції за межі України, тис. грн }\end{array}$} & \multicolumn{3}{|c|}{$\begin{array}{c}\text { Відсоток реалізованої } \\
\text { інноваційної продукції за меж } \\
\text { України загального рівня } \\
\text { реалізованої інноваційної } \\
\text { продукції, \% }\end{array}$} \\
\hline & 2016 & 2017 & 2018 & 2016 & 2017 & 2018 & 2016 & 2017 & 2018 \\
\hline Вінницька & 8 & 9 & 9 & 131675,6 & 165835,4 & 173241 & 35,5 & 39,2 & 40,3 \\
\hline Житомирська & 7 & 7 & 9 & 112528 & 132298,2 & 152621 & 23,5 & 25,6 & 30,2 \\
\hline Київська & 6 & 8 & 9 & 205429 & 226954 & 235410 & 27,8 & 29,5 & 31,5 \\
\hline Хмельницька & 1 & 1 & 1 & - & - & - & - & - & - \\
\hline Черкаська & 7 & 9 & 8 & 168369 & 258361 & 201587 & 12,6 & 22,4 & 19,3 \\
\hline Чернігівська & 0 & 0 & 2 & 108745 & 129432 & 143290 & 12,4 & 15,3 & 16,9 \\
\hline Україна & 167 & 179 & 193 & 4358998,6 & 5518834,9 & 6118634,9 & 29,8 & 31,2 & 34,1 \\
\hline
\end{tabular}

Таблиця 5 - Динаміка інтегрального показника розвитку інноваційного потенціалу Центрального регіону України у 2016-2018 роках

\begin{tabular}{|c|c|c|c|c|}
\hline Показник & 2016 & 2017 & 2018 & Вага, \% \\
\hline $\begin{array}{l}\text { Кількість промислових підприємств, що впроваджували інноваційні } \\
\text { процеси, од. }\end{array}$ & 0,411 & 0,379 & 0,500 & 0,05 \\
\hline $\begin{array}{l}\text { Кількість промислових підприємств, що впроваджували нові або } \\
\text { вдосконалені методи обробки або виробництва продукції, од. }\end{array}$ & 0,480 & 0,467 & 0,443 & 0,1 \\
\hline $\begin{array}{l}\text { Кількість промислових підприємств, що освоювали виробництво } \\
\text { інноваційних видів продукції, од. }\end{array}$ & 0,433 & 0,414 & 0,366 & 0,1 \\
\hline Кількість промислових підприємств, що освоювали нові технології, од. & 0,510 & 0,407 & 0,435 & 0,1 \\
\hline Кількість підприємств, що реалізували інноваційну продукцію, од. & 0,607 & 0,593 & 0,605 & 0,05 \\
\hline $\begin{array}{l}\text { Кількість підприємств, що реалізували продукцію, що була новою для } \\
\text { ринку, од. }\end{array}$ & 0,375 & 0,524 & 0,500 & 0,05 \\
\hline $\begin{array}{l}\text { Кількість підприємств, що реалізували продукцію, що була новою тільки } \\
\text { для підприємства, од. }\end{array}$ & 0,655 & 0,635 & 0,648 & 0,05 \\
\hline $\begin{array}{l}\text { Кількість організацій, які виконують наукові та науково-технічні роботи за } \\
\text { регіонами, од }\end{array}$ & 0,491 & 0,470 & 0,460 & 0,05 \\
\hline $\begin{array}{l}\text { Кількість виконаних наукових та науково-технічних робіт за регіонами, } \\
\text { тис. грн }\end{array}$ & 0,321 & 0,333 & 0,325 & 0,1 \\
\hline $\begin{array}{l}\text { Обсяг наукових та науково-технічних робіт, виконаних власними силами } \\
\text { наукових організацій за регіонами, тис. грн }\end{array}$ & 0,642 & 0,552 & 0,481 & 0,1 \\
\hline $\begin{array}{l}\text { Кількість підприємств, що реалізували інноваційну продукцію за межі } \\
\text { України, од. }\end{array}$ & 0,604 & 0,630 & 0,667 & 0,05 \\
\hline Обсяг реалізованої інноваційної продукції за межі України тис. грн & 0,590 & 0,589 & 0,642 & 0,1 \\
\hline $\begin{array}{l}\text { Відсоток реалізованої інноваційної продукції за межі України до } \\
\text { загального рівня реалізованої інноваційної продукції, \% }\end{array}$ & 0,525 & 0,561 & 0,572 & 0,1 \\
\hline Інтегральний показник & 0,046 & 0,146 & 0,117 & - \\
\hline
\end{tabular}


на низькому рівні. Відповідно, це визначає можливості інноваційного розвитку на основі кластерного підходу.

Висновки. Проведене дослідження слугує підставою для формулювання висновку щодо неготовності Центрального регіону України до стрімкого розвитку інноваційного потенціалу. Вихідні умови для виробництва інноваційної продукції промисловими підприємствами не сприяють покращенню рівня інноваційності. Перешкодами є відсутність ефективних державних інструментів підтримки інновацій, таких як: фінансове сприяння промисловим підприємствам шляхом пільгового оподаткування, компенсації відсоткової ставки підприємствам, які впроваджують інноваційні процеси, компенсації підприємствам, які орієнтовані на експорт високотехнологічної продукції, місцеві стимули. Подальші дослідженні доцільно спрямувати на висвітлення локальних та національних інструментів інноваційної підтримки промислових підприємств.

\section{Список використаних джерел:}

1. Afandi E., \& Kermani M. What determines firms' innovation in Eastern Europe and Central Asia. Perspectives of Innovations, Economics and Business. 2014. Vol. 14(1). P. 1-20. doi:10.15208/pieb.2014.01

2. Bagaryakov A.V. Innovative security in the system of economic security of the region. Economics of the region, 2012. Vol. 2. P. 302-305.

3. Ebersberger B., \& Mevenkamp N. Open Innovation in Eastern Europe and Central Asia. Journal of Business Administration Research. 2016. Vol. 5(2). doi:10.5430/jbar.v5n2p8

4. Fagerberg J. Innovation policy: rationales, lessons and challenges. Journals of Economic Surveys, 2016. Vol. 31(2). P. $497-512$. 5. Fan P. Innovation in China. Journals of Economic Surveys, 2014. Vol. 28 (4). P. 725-745.

6. Krajewski, S. Innovation Levels in the Economies of Central and Eastern Europe. Comparative Economic Research. 2014. Vol. 17(3). P. 101-122. doi:10.2478/cer-2014-0025

7. Kuznetsova, M.V. Innovation management as part of economic security. Journals National Interests: Priorities and Security, 2019. Vol. 15 (1). P. 53-63.

8. Omelyanenko, V., Biloshkurskyi, V. Methodology of national investment and innovation security analytics. Problems and Perspectives in Management. 2019. Vol. 17(1). P. 380-394.

9. Puślecki, Z. W. Region, innovation and knowledge in strategy of European Union economic growth and social security. Rocznik Integracji Europejskiej. 2015. Vol. 9. P. 123-132.

10. Widmaier, B. Knowledge and Innovation in Industry in Central and Eastern Europe. Institutional Change and Industrial Development in Central and Eastern Europe. 2018. Vol. 5, P. 175-193. doi:10.4324/9780429457272-10

11. Глізнуца М. Ю. Управління розвитком інноваційного потенціалу України та регіонів : дис. ... канд. економ. наук; Харківський політехнічний інститут. Харків, 2018. 247 с.

12. Глізнуца М.Ю. Визначення складових та оцінка інноваційного потенціалу регіону. Technology audit and production reserves. 2016. № 3/5. С. 11-14.

13. Долішній М.І., Паламарчук М.М., Паламарчук О.М., Шевчук Л.Т. Соціально-економічне районування України. Львів: НАН України; Інститут регіональних досліджень, 1997. 50 с.

14. Про схвалення Стратегії розвитку сфери інноваційної діяльності на період до 2030 року. URL: https://zakon.rada.gov.ua/ laws/show/526-2019-р (дата звернення : 28.05.2020)

15. Чемерьова Л. Ю., Федяй Н. О. Районування територій України як один із факторів просторового соціально-економічного розвитку регіонів. URL: http://www.economy.nayka.com.ua/?op=1\&z=1878 (дата звернення : 28.05 .2020 p.)

\section{References:}

1. Afandi E., Kermani M. (2014) What determines firms' innovation in Eastern Europe and Central Asia. Perspectives of Innovations, Economics and Business, 14(1), 1-20. doi:10.15208/pieb.2014.01

2. Bagaryakov A.V. (2012) Innovative security in the system of economic security of the region. Economics of the region, 2, 302-305.

3. Ebersberger B., \& Mevenkamp N. (2016). Open Innovation in Eastern Europe and Central Asia. Journal of Business Administration Research, 5(2). doi:10.5430/jbar.v5n2p8

4. Fagerberg J. (2016) Innovation policy: rationales, lessons and challenges. Journals of Economic Surveys, 31(2), $497-512$.

5. Fan P. (2014) Innovation in China. Journals of Economic Surveys, 28 (4), 725-745.

6. Krajewski S. (2014) Innovation Levels in the Economies of Central and Eastern Europe. Comparative Economic Research, 17(3), 101-122. doi:10.2478/cer-2014-0025

7. Kuznetsova M. V. (2019) Innovation management as part of economic security. Journals National Interests: Priorities and Security, 15 (1), 53-63.

8. Omelyanenko V., Biloshkurskyi, V. (2019) Methodology of national investment and innovation security analytics. Problems and Perspectives in Management, 17(1), 380-394.

9. Puślecki Z.W. (2015) Region, innovation and knowledge in strategy of European Union economic growth and social security. Rocznik Integracji Europejskiej, 9, 123-132.

10. Widmaier B. (2018) Knowledge and Innovation in Industry in Central and Eastern Europe. Institutional Change and Industrial Development in Central and Eastern Europe, 5, 175-193. doi:10.4324/9780429457272-10

11. Gliznutsa M.Yu. (2018) Upravlinnia rozvytkom innovatsiinoho potentsialu Ukrainy ta rehioniv [Management of development of innovative potential of Ukraine and regions] (PhD Thesis). Kharkiv: Kharkivskyi politekhnichnyi instytut.

12. Gliznutsa M.Yu. (2016) Identification of components and assessment of the innovation potential of the region. Technology audit and production reserves, 3/5, 11-14.

13. Dolishniy M.I., Palamarchuk M.M., Palamarchuk O.M., Shevchuk L.T. (1997) Sotsialno-ekonomichne raionuvannia Ukrainy [Socio-economic zoning of Ukraine. NAS of Ukraine]. Lviv: Institute of Regional Studies (in Ukrainian)

14. Pro skhvalennia Stratehii rozvytku sfery innovatsiinoi diialnosti na period do 2030 roku [On approval of the Strategy for the development of innovation for the period up to 2030]. URL: https://zakon.rada.gov.ua/laws/show/526-2019-p (accessed 20.03.2020)

15. Chemeryova L.Yu., Fedyai N.O. (2020) Raionuvannia terytorii Ukrainy yak odyn iz faktoriv prostorovoho sotsialnoekonomichnoho rozvytku rehioniv [Zoning of Ukraine as one of the factors of spatial socio-economic development of regions]. URL: http://www.economy.nayka.com.ua/?op=1\&z=1878 (accessed 20.03.2020) 
Shashyna Maryna

National Technical University of Ukraine "Igor Sikorsky Kyiv Polytechnic Institute"

\section{LEVEL OF INNOVATIVE POTENTIAL OF THE CENTRAL REGION OF UKRAINE}

Taking into account the actualization of the implementation of the cluster approach to the development of the innovation sphere, the aim was to investigate the innovation potential of the Central region of Ukraine on the basis of the system of indicators of innovation activity. The methodological basis of the article is zoning method developed by scientists of the National Academy of Sciences of Ukraine, methodological approaches to zoning, the method of grouping components for the analysis of innovation potential. To assess the innovation potential, an evaluation method based on an integrated indicator is proposed. To determine it, the normalized values of innovation potential indicators based on deviations ( $x$ ij-a) and standardization of indicators with a range of variation based on the minimum and maximum values of indicators were used. Based on the integrated index of innovation potential, the article evaluates the level of innovation in the Central region of Ukraine. The concept of innovation potential and factors of its development are defined. Processes in the field of innovation activity of the region are investigated. Positive and negative trends in the field of innovation are identified. The lack of implementation of a cluster approach to the realization of innovation potential has been established. A number of tendencies in the level of innovation potential of the Central district were revealed: stability of introduction of innovations by industrial enterprises, development of production of innovative products, new technologies, introduction of new technologies and innovative processes. No changes in the preconditions for the development of the innovation sphere have been revealed. The introduction of innovation processes in enterprises was a stimulating factor for innovation development in 2018. In general, the high-technology of the economy of the Central region of Ukraine remains low. Accordingly, it identifies opportunities for innovative development based on a cluster approach. Prerequisites for expanding innovation potential are local and national incentives: financial assistance to industrial enterprises through preferential taxation, interest rate compensation to enterprises that implement innovationbl, compensation to enterprises focused on the export of high-tech products, local incentives.

Key words: innovation potential, level of innovation development, high-tech sector, cluster approach.

JEL classification: O3 